\title{
Research on Administrative Omission
}

\author{
Chunye Ren \\ Department of Journalism,School of \\ Humanities and Law \\ Shenyang Radio and Television University,SYTVU \\ Shenyang, Liaoning Province, China \\ rcy459045@163.com
}

\author{
Haotong Yang \\ Japanese Department;Foreign Studies \\ ollege;International Economic Law,Continuing \\ Education College \\ Northeastern University,NEU \\ Shenyang, Liaoning Province, China \\ Yanghaotong.yht@gmail.com
}

\begin{abstract}
Administrative omission is a kind of serious illegal administrative action. It infringes the administrative counterparts' rights, even the nation and public interests. Therefore, the academic research of the administrative omission deeply and systemically is an essential segment of improving the whole theory of administrative actions.
\end{abstract}

Keywords-Administrative omission; Legal liability; Control

\section{INTRODUCTION}

The administrative omission is an important part of the theory of administrative behavior. The administrative omission is that the Chief executive has positive as the administrative duty, and it has the possibility to do, but the procedure a reasonable period beyond the statutory period or do certain things negative administrative violations. Its essence is the administrative body negative give up a kind of administrative power of illegal administrative behaviors. Theoretical terminology of the administrative omission has been China's administrative law scholars widely accepted, and was applied in the administrative legislation, administrative enforcement, administrative review and administrative litigation practice. Administrative omission and administration as legal and illegal two possibilities are compared, Administrative omission is illegal. If you do not have a law to regulate, for the administrative body, administrative omission offense will become the legal excuse, the administrative relative person's legitimate rights and interests will be more subtle than administration as illegal infringement, lead to the overall national inefficient law enforcement, law enforcement authority to drop, appear even directly harm the interests of the state and the adverse consequences. Therefore, we should be more in-depth on the administrative omission and other issues, and improve the corresponding relief system.

\section{SUMMARY OF THE ADMINISTRATIV OMISSION}

In recent years, with the gradual improvement of the legislation and the enhancement of people's law consciousness, especially the administrative litigation indepth,citizens, legal persons and other organizations to sue the administrative organ isnot as case quantity rise suddenly, administrative omission phenomenon caused bythe masses of the people and the social widespread attention from all walks of life. So how do we define administrative omission?

\section{A. The Concept of Administrative Omission}

Administrative omission means the administrative subject has positive as administrative obligation, and has as a possibility, but more than the statutory period or a reasonable period, negative and not for administrative illegal behavior.

The view of administrative omission is that the administrative main body does not fulfill the legal duties, and it is compared with the current administrative procedure law. Administrative omission and non-performance of statutory duties have certain connection, but the two are not a concept. The scope of administrative omission is greater than the nonperformance of statutory duties. If in accordance with the current laws and regulations, It is a main part of the administrative non-performance of statutory duties outside the administrative obligation violation of the administrative relative person's legitimate rights and interests cannot get judicial remedy, as the administrative subject does not perform the obligations stipulated in the contract, does not perform the administrative relative person's commitment to [1].

Both never perform their statutory duties and administrative omission of the connotation or denotation, the two both have big difference. Non-performance of statutory duties is refers to the administrative subject has the laws, administrative regulations, local regulations, autonomous regulations or separate regulations and rules of responsibility, the ability to perform and express refusal to perform or no response to [2]. In fact the administrative litigation law is only non-performance of statutory duties, but not for the executive is not as stipulated. Administrative omission is that the administrative subject has as administrative obligation, the ability to perform in the procedure does not perform or delays the performance behavior. The administrative body which bear the administrative obligation already contains statutory obligations, or statutory duties, also contains a legal obligation other than administrative obligation [3].

\section{B. The Characteristics of Administrative Omission}

\section{1) Negative resistance}


Negativity in subjective performance for the administrative subject to its administrative powers to give up, in on is objective is not to perform or delay the performance of the administrative duties. The administrative authority derived from legal authorization, the administrative subject can only be strictly in accordance with the law to exercise the rights, obligations, administrative subject cannot abandon obligation, also cannot abandon the right. "The responsibility of administration" is modern administrative law's basic concept, also be a government under the rule of law should abide by the basic principle of [4]. Administrative nonfeasance is actually right and responsibility serious separation performance, is the administrative body to the right for the protection of negative evade obligations. At the same time as a result of the interest drive, the administrative body in the exercise of administrative powers, often consider small collective interests, when there is no interest or interest for hours, often occur in the administrative omission.

\section{2) Procedure}

Judgment of administrative behavior is the action or inaction, the most basic is to see whether the start and finish of the administrative procedure. Start administrative procedure mainly means in accordance with the application of administrative behavior, administrative license, including: administrative benefit, administrative confirmation administrative decisions and administrative incentives and behavior. The relative people after a request from the administrative subject should start the administrative program, eligible to accept, do not meet the conditions in the informed reasons after rejecting. Of course, there are ex officio administrative behavior, including: planning administration, administrative order, administrative expropriation, administrative punishment, administrative enforcement act [5]. Therefore, procedure of administrative omission is a very important characteristic.

\section{3) Illegality}

Illegality is administrative omission's essence features. As a result of administrative subject in legal time limit or within a reasonable time to perform their administrative duties of administrative subject, so, once considered an administrative omission, means that the administrative omission necessarily illegal. Theoretically there is no legitimate administrative omission, legitimate administrative action is not necessarily an administrative omission. Some scholars believe that the legal attribute of administrative omission is to be on the legality of the evaluation of the administrative behavior, administrative omission in the people's court before the referee only that there is the possibility of illegal, not reality [6]. This is in itself should be said that there is no error, but the problem is that we are not in a specific without judicial confirmation of administrative nonfeasance case, but in the discussion the essential feature of administrative omission, so I think the administrative omission has illegal characters is the premise of administrative behavior of administrative omission, if not an administrative omission, of course, cannot say that this action is illegal.

4) Non discretionary
Administration as a striking feature is the administrative body has more discretion. Although the law society requests the administration must be in accordance with the law, but as a result of administrative extensive, complex and unpredictable, so the law cannot be administrative management of all matters, administrative act of every step, every detail to make specific, maneuverability is strong rules, so the administrative behavior and the judicial behavior are compared, administrative discretion is far greater than that of judicial conduct. But in the case of administrative omission, the administrative body that discretion is strictly restricted, administrative subject must fulfill its assume administrative responsibility, cannot give up to perform, also cannot shuffle, delay in performing obligations, administrative body in no choice than to. The administrative subject in administrative relative person's application for receiving or ex officio found relatively people need to get relief after, should immediately start the administrative procedure, and legal or equitable completed during the administrative procedure, administrative subject on this problem cannot discretion.

\section{Constitutive Requirements of Administrative Omission}

The establishment of administrative omission must have constitutive requirements, accurate understanding and grasp the elements of administrative omission is the administrative trial practice the proper adjudication of administrative omission in the critical case. Administrative omission has the following four components:

1) Main body of administrative omission must be the administrative subject

The subject of administration is a subject of administrative law. The administrative subject in administrative legal relationship may exist, but in a variety of administrative legal relationship, it is relation party, and the other party constitute corresponding to both sides of the relationship. According to the laws of China and the theory of administrative law, administrative subjects include the administrative organs and the authorized by laws and regulations, organizations, specifically refers to the name of their external independent exercise of administrative powers and legal liability of an administrative organ or organization authorized by the laws, rules and regulations.

2) The administrative body has the administrative duties as

As mentioned before, administrative obligation already have statutory obligations, there are illegal duty, but no matter what kind of obligation, the administrative subject unique identity, are required to perform administrative duties.If the administrative subject does not exist must fulfil administrative obligation, there would be no administrative omission.

3) The administrative subject has the possibility to perform administrative duties

Although the administrative subject has administrative duties, but because of objective conditions, as well as the force majeure accident, leading to the administrative subject and its staff due to the subjective reason fail to fulfil administrative obligation, cannot be identified as 
administrative omission. Only in the administrative subjects have to fulfill the obligation of possibility, and as a result of intentional or negligent not in legal or equitable period as, can constitute the administrative omission.

The fact is not fulfil administrative obligation

Administrative main body in the objective has in legal or reasonable time limit does not fulfil administrative obligation facts. The administrative subject does not perform administrative duties in the judicial practice is generally manifested in two forms: One is the administrative body in the received relative to the application or ex officio, finding that the relative person 's rights or property in need of protection situation, no priming of administrative procedure, which belongs to complete administrative omission. Another form is the administrative body although the initiation of administrative procedure, but in legal or within a reasonable period of time not completed administrative procedure, which belongs to the imperfect administrative omission, may also say that delays in the fulfilment of obligations. For example, in the cases of administrative reconsideration, administrative subject while receiving the relative application, also had the necessary audit, but within the statutory period neither to relative people make the decision of reconsideration, nor to the relative person told not grounds of decision. Better master the legal time limit, there are laws, regulations clear, how to grasp the reasonable period of time, in judicial practice, there is no uniform standard, although the Supreme Court "on the implementation of 'Administrative Procedure Law of the people' s interpretation of several issues" provisions of the two month period, but in some cases not applicable two months of provisions, so it should be based on specific cases, judicial review is not only beneficial to protect the legal rights and interests, improve administrative efficiency, but also to take care of the administrative body of the actual situation, not make things difficult for the administrative subject [7].

To sum up, the conduct of the administrative body must also comply with the above four elements, to make the administrative omission.

\section{THE LEGAL RESPONSIBILITY OF ADMINISTRATIVE OMISSION}

Have the right to must have the responsibility of administrative omission, as a kind of illegal administrative acts, the subject must bear the corresponding legal responsibility. At present, for the administrative omission caused by the legal responsibility, theoretical research mainly limited liability in administrative indemnity. But the author discovers in research, hand, not all the executive is not as required by the administrative organ damages, on the other hand, the relevant responsible person of the law is almost blank, which led to the practice of many drawbacks, such as no damage or no applicant of administrative omission often do not add investigation on the corresponding responsibility, the lack of legal basis and the treatment. Therefore, systematic framework of administrative omission of legal liability system is very necessary.

\section{A. Administrative Liability for Fault}

As mentioned earlier, not all administrative omission are required for administrative compensation. But according to the penalty the consistency principle, the law is not allowed to have illegal action without legal responsibility to recover. Otherwise, it will lead to administrative organs and their staff "dare to do small things, generous, to avoid" serious violation of public interests and the legitimate interests of the relative. To this, in the "civil law" before the implementation of the administrative organs, mostly rely on internal rules and regulations will be punished. With the implementation of "civil law" and the State Council vigorously carrying out of administrative law enforcement responsibility system , without the need for administrative compensation for administrative omission sanctions, already gradually by the past pure internal restriction to basis law treatment. In the division of responsibilities, authorities, law enforcement through decomposition of determining responsibility for law enforcement as determined by every post, every law enforcement law enforcement responsibility to determine; in accountability, a warning, demerit, demotion, dismissal, serious, fired six. That is, the administrative liability should not only include the administrative organs on the staff of administrative nonfeasance in accordance with the law, should also have the administrative organs to relative person hurts to give appropriate compensation or representation form, as a public apology, eliminating effect. At the same time should be affirmed, administrative liability for fault does not affect the administrative compensation, whereby the need for administrative omission liability, administrative liability and administrative liability can exist at the same time [8].

\section{B. The Liability of Administrative Compensation}

The liability of administrative compensation is administrative omission bear legal responsibility main types, but also protect the legitimate rights and interests of the relative major way. As mentioned earlier, not all administrative omission will have administrative compensation. Then, the executive is not as the constitutive elements of compensation liability which to have?

Combined with the current theoretical research results, this paper considers mainly as follows: A. Has administrative omission exists objectively, which must satisfy the above administrative omission elements. B. Has against the legitimate rights and interests of the relative determination, realistic damage occurs. This includes three meanings: first, there must be the presence of actual damage. The damage must be identified, in reality. Both the direct loss of vested interest, including the expected benefits, which will be of interest occurred can be determined by the indirect loss. But for the uncertain status of damage, because it is not realistic and certainty, should not be compensated. Second, damage must be relative to the human rights of the individual. China is still no national law laws and regulations, so, if the executive is not as simply caused the loss of public interest, and no infringement of the rights and benefits of the relative, do not create liability. Third, damage must be relative to the 
legitimate rights and interests. If the relative human behavior itself is illegal administrative subject administrative omission, because of the damage caused by natural without compensation. But you need to pay attention, sometimes despite the relative human behavior itself is illegal, but the executive is not as damaging their unlawful interests at the same time, the legitimate rights and interests or other relative people's legitimate rights and interests of damage, the same should be in the scope of compensation for damage in [9]. C. Administrative omission and the damage on the causal relationship between law.The article thinks, law of causality is different from ordinary causation, not simply from "external conditions" and "reason" to analyze, and should take the damage occurrence and outcome of administrative omission is whether there is a correlation between the content of as.As long as the administrative main body as the obligation is to protect the relative people of the administration settings without the benefit of the administrative subject, and breach of obligation and cause specific administrative relative person of the administrative subject loss, not as an administrative tort, it and the administrative relative person damage results in a causal relationship between. Whether it is the direct cause, or external conditions, should be considered and damage results between legal causation.

\section{Criminal Responsibility}

As a kind of administrative actions, the executive is not as research mostly limited to administrative jurisprudence, but the administrative omission from legal responsibility to carry on the analysis, it inevitably involves the science of criminal law. Part of the administrative omission because, once more than the administrative legal relationship of the critical point, often constitutes a criminal offence.This is in our country criminal law is not uncommon, and most of them are in the ninth chapter of crime of dereliction of duty. As of 404th the play favouritism and commit irregularities not syndrome or undercollect tax crime, the 405th play favouritism and commit irregularities sale of invoices, tax, export tax rebates, 408th environmental supervision of crime of dereliction of duty, 409th animal and plant quarantine dereliction of duty crime, at the same time, there is no can be applied directly to the administrative omission, can apply the article 397th crime and crime play favouritism and commit irregularities be forgetful of one's duties. Simple analysis is not difficult to see that the two characteristics: first, the law has never occurred in the administrative omission words; secondly, the law does not have to be administrative subject as the subject of crime, but only to the main responsibility person or persons directly responsible and subject of crime. This is the theory in the study of administrative omission is rarely involved in criminal law mainly because, after all, administrative omission should be the mainstay of the administrative organ or the organization authorized by law, and is not a personal [10]. Moreover, in the investigation of the administrative omission of legal liability, is often involved in administrative compensation, and one case of simultaneous presence of criminal legal relation and the administrative legal relationship, the theory and the practice has not too much precedent, various legal relationship of the parties is not well defined, and even appear to conflict.

\section{SUPERVISION OF ADMINISTRATIVE OMISSION}

\section{A. The Authority of The Supervision}

Authority of the administrative omission supervision mainly through three ways: A. legal supervision: the people's Congress and its Standing Committee of the local people's government supervision of adherence to and implementation of the Constitution and the laws, regulations and laws, rules and regulations of the resolution of the situation, the administrative body and its staff do not perform their statutory obligation of administrative act of administrative omission, inevitable to supervise; B. work supervision: the people's Congress and its Standing Committee and the people's Congress of the main administrative supervision, to ensure that the administrative work in compliance with the will of the people, the way to remedy for administrative omission includes handling letters and visits and complaints, citizen deputies to the administrative omission to exercise the right question right and inquiries, Organization Committee of inquiry into specific questions on the administrative process occurred causing catastrophic consequences of administrative omission investigation; C. personnel supervision: For those in the administrative omission in the responsible government personnel to be replaced.

\section{B. Judicial Supervision}

The people's Procuratorate as state legal supervision organ, for administrative omission supervision mainly through administrative crimes were investigated, such as state functionaries of the administrative organ in the administrative omission in the serious dereliction of duty, dereliction of duty crime investigation.

The people's court for judicial review of administrative nonfeasance, as citizens, legal persons or other organizations for administrative organs illegally is not as to their legitimate rights and interests suffer damage provides the most fair, most effective relief.

\section{Administrative Supervision}

The administrative organ in the administrative reconsideration relief ways including outside: 1. General supervision organs relief: related people's Government of the remedy for administrative omission, except as an administrative reconsideration organ for confirmation, perform, can work report, investigation and inspection, review, criticism and disposal way of relief;2. Administrative supervision organ relief: as the competent authority, in addition to the main as an administrative reconsideration organ shall be relief, but also through inspection, examination and special examination and other means, to the competent authorities of lower administrative omission corrected, can be programmed, can also include substantial performance, even in special circumstances directly on the administrative omission should be as the statutory obligations to fulfill;3. Special supervision in the administrative supervision of relief: administrative 
supervision is mainly through the refusal to enforce laws, rules and regulations of administrative omission recommend supervision or make a supervisory decision way to remedy.

Have the right to must have the responsibility of administrative omission, as a kind of illegal administrative acts, the subject must bear the corresponding legal responsibility. At present, for the administrative omission caused by the legal responsibility, theoretical research mainly limited liability in administrative indemnity. But the author discovers in research, hand, not all the executive is not as required by the administrative organ damages, on the other hand, the relevant responsible person of the law is almost blank, which led to the practice of many drawbacks, such as no damage or no applicant of administrative omission often do not add investigation on the corresponding responsibility, the lack of legal basis and the treatment. Therefore, systematic framework of administrative omission of legal liability system is very necessary.

\section{ACKNOWLEDGMENT}

In the process of writing, I has learned a lot from theory predecessors, and corrected my own mind about thesis and some of my own misunderstanding of expertise, finally finished the ends of the paper. I sincerely thank my friends, who devoted their efforts and patience to each chapter and progress in every step in my thesis.

\section{REFERENCES}

[1] Sun Xing, Zhiqiang, Zhang Zongping. Discussion on the definition of administrative omission and its constitutive elements [J]. administrative law, 2006, (4): 55.

[2] Zhou Youyong. The executive is not as judgment [M]. Wuhan University press, 2008:61.

[3] Wang Fangdong. Administrative omission [J]. seek truth from facts, 2010, (1): 78 .

[4] Weng Yuesheng. Administrative law [M]. China Legal Publishing House, 2009:112

[5] Wang Mingyang. Comparative administrative law [M], Peking University Press, 2006:211.

[6] Ding jia. On the administrative omission illegality [J]. legal system and society, 2010, (7): 157.

[7] Sun Ping. Administrative law case [M]. Wuhan University Press, 2008:55.

[8] Su Zuqin. Administrative law [M]. Wuhan University press, 2008:235.

[9] Tang Ji'an. Administrative omission and its compensation responsibility of [J]. enterprise science and technology, 2008, (4): 89.

[10] Chen Juncheng. On the legal responsibility of administrative omission [J]. legal system and society, 2009, (7): 98 . 